\title{
Bringing Actors Back in : Political Choices and Sources of Post-Soviet Regime Dynamics
}

\section{Gelman, Vladimir}

2018-09

Gelman , V 2018 , ' Bringing Actors Back in : Political Choices and Sources of Post-Soviet

Regime Dynamics ' , Post-Soviet Affairs , vol. 34 , no. 5 , pp. 282-296 . https://doi.org/10.1080/1060586X.2018.1493

http://hdl.handle.net/10138/312861

https://doi.org/10.1080/1060586X.2018.1493785

unspecified

acceptedVersion

Downloaded from Helda, University of Helsinki institutional repository.

This is an electronic reprint of the original article.

This reprint may differ from the original in pagination and typographic detail.

Please cite the original version. 


\title{
Bringing actors back in: political choices and sources of post-Soviet regime dynamics
}

\author{
Vladimir Gel'man* [Query 1] \\ Faculty of Political Science and Sociology, European University at St Petersburg; St. Petersburg, Russia \\ and Aleksanteri Institute, University of Helsinki, Helsinki, Finland
}

(Received 27 February 2018; accepted 20 June 2018)

*Email: vgelman@eu.spb.ru

\begin{abstract}
One might summarize the state of the field of research into contemporary Russian politics as a "dismal consensus": most observers believe that durable authoritarianism has consolidated itself, and there is very little chance of democratization in the foreseeable future. Many barriers to democratization, such as an unfavorable international environment and the persistence of non-democratic legacies, as well as the entrenchment of the state's use of coercion and repressions, seem insuperable in the short term. However, political regime changes are often launched and develop over time as side effects of moves made by political actors, and their outcomes are not predetermined. This article aims to go beyond this "dismal consensus," and revisits some of the arguments on the role of structure and agency in post-Soviet regime dynamics. Apart from the changes in structural variables, it reconsiders the role of the incentives and choices of selfinterested political actors, who are not always omnipotent and well-informed strategists. The overall dismal tendencies nevertheless leave some "bias for hope" in the analysis of regime dynamics in post-Soviet Eurasia and beyond.
\end{abstract}

Keywords: democracy, authoritarianism, regime dynamics, Eurasia, political science

\section{Introduction: beyond the dismal consensus}

In all likelihood, the early 1990s were the happiest time in history for scholars of democracy. The fall of the Berlin Wall and the subsequent collapse of communism had seemingly paved the way to the global triumph of democracy, and the overall political trajectory was perceived to be heading toward the "end of history" (Fukuyama 1992), the outcome of the Manichean conflict between good and evil. Dozens of books and hundreds of articles with very promising titles such as "From Communism to Democracy" reflected the widespread optimism about the future of democracy and positive perceptions of political dynamics in Europe, Eurasia, and elsewhere. In a way, this understanding was similar to the scenarios of many Hollywood movies, which are usually based on similar kinds of conflict between "good guys" and "bad guys," with the expectation that the "good guys" will inevitably prevail and give the film a happy end. In practice, real life is much more complex than Hollywood movies, and political life is no exception. The times of Great Expectations of the early 1990s turned into the times of Great Disillusionment of the late 2010s. In sharp contrast with the rising optimism of the early 1990s, many (if not most) scholars, observers, and analysts now tend to perceive recent political developments in the post-communist world and beyond as virtually hopeless. In cinematographic terms, one might compare 
this to a shift from the Hollywood movie paradigm of political thought to the predominance of film noir thinking about politics. It is based upon a belief that there is no such thing as "good guys," all "guys" are exclusively bad, and the overall perceptions of global political dynamics today and tomorrow are essentially dismal. On the one hand, democratic ideals have recently been questioned if not discredited due to the rise of new challenges for advanced democracies and the imperfect responses of democratic governments amid the global trend of new populism, and the discreet charm of authoritarian rule has reinvented itself across the world (very often under the primitive logic of "the enemy of my enemy is my friend"). On the other, some authoritarian regimes have proved resilient enough to ensure their survival, while both old and new democracies in many parts of the globe (and not only in post-Soviet Eurasia) have demonstrated numerous problems with their economic and political performance. The partial restoration of the real or imagined "good old" non-democratic political order is now often considered as a viable alternative to the unpalatable status quo.

It is no wonder that these political tendencies have greatly contributed to the current state of the art in research of political regime dynamics in post-Soviet Eurasia: in essence, it may be labeled a "dismal consensus." Deriving from the fact that none of the 12 countries of the former Soviet Union (except for the Baltic states) have built a stable electoral democracy after a quarter century of independence, scholars with a variety of views and approaches do not expect further democratic advancement for these countries at least in the foreseeable future. As for Russia, it is almost universally perceived as a case of durable authoritarianism, and the title of the recent book Will Putin's System Survive until 2042? (Travin 2016) may summarize the mainstream perceptions of this country's political future. At best, scholars express some hope for the long-term effects of economic growth, which, alongside generational changes, may lay down favorable conditions for democratization in Russia some decades from now (Hale 2015; Treisman 2015). Although economic experts express skeptical opinions about Russia's prospects for sustainable growth and development amid turbulent oil prices and international sanctions (World Bank 2017), even the political scientists' cautiously positive outlook reminds one of a statement by the nineteenth-century Russian poet Nikolai Nekrasov, who predicted the bright yet very distant future of Russia in his The Railway (1864): "Alas! That the day of our joyful tomorrow // I shall not witness-and neither shall you."

However, the rise of the dismal consensus over the political prospects of Russia and Eurasia only to some degree reflects the pattern of ongoing political changes. It also demonstrates the shift of scholarly focus from agency-driven to structure-induced explanations of political changes in post-Soviet Eurasia and beyond. The research into the Third Wave of democratization in the 1980s primarily concentrated on the key role of agency in the demise of authoritarian regimes in Latin America and Eastern Europe (O'Donnell, Schmitter, and Whitehead 1986; Huntington, 1991; Przeworski, 1991) through the lenses of analyses of conflicts and coalitions of political actors during the process of political regime changes. Conversely, major explanations of the rise of new post-communist authoritarianism are predominantly structural and refer to a variety of non-economic factors. Their list ranges from the persistence of legacies of bad informality ("sistema") (Ledeneva 2013) and of "patronal politics," which tend to reproduce "single power pyramids" in the region over time (Hale 2015), to the impact of the strength of the state and/or ruling parties and weakness of international linkages between these countries and Western democracies (Levitsky and Way 2010). While actor-based perspectives on post-Soviet authoritarianism have not disappeared entirely, they largely attempt to explain these political developments through the personal traits of Vladimir Putin and other post-Soviet leaders, whom they portray as "bad guys" who have seized and usurped power by chance, impose their kleptocratic rule in their respective countries, and export it abroad (Hill and Gaddy 2013; Dawisha 2014; Cooley and Heathershaw 2017). Although 
many of these negative assessments of post-Soviet leaders appear accurate in factual terms, they are insufficient for theoretically solid analyses of causes and effects of the new post-Soviet authoritarianism.

This pendulum-like swing from agency to structure in the research on post-Soviet political regime dynamics seems paradoxical in two respects. First, the experience of post-Soviet Eurasia is contrary to conventional wisdom on the key role of major economic structural variables in the dynamics of political changes in comparative perspective. For example, economic development in Russia coincided with the process of its regime changes according to the pattern of "more development-less democracy" (Colton 2017), contrary to the predominant explanations of the "prerequisites" of democracy in the literature (Lipset 1959). In a similar vein, the degree of socio-economic inequality in the region, while having increased after the Soviet collapse, is still lower than in many Latin American democracies (Remington 2011), so one should not claim the rise of inequality in post-Soviet Russia (Novokmet, Piketty, and Zucman 2017) to be the main cause for its non-democratic trajectory. Even the inclusion of additional economic structural variables such as the pernicious political effects of the "resource curse" (Ross 2012) has not added much to this picture in oil-rich countries such as Russia (Treisman 2011). Judging by all economic structural variables, one might expect that Russia and Eurasia should be more politically open than they are evaluated to be by various agencies. Thus, it is not so clear why some (non-economic) structural explanations of post-Soviet durable authoritarianism are effective while others (economic) are not. Second, one might be puzzled by a certain theoretical inconsistency. Why has the collapse of Soviet communism been rather successfully explained through the prism of numerous actor-based analyses (Solnick 1998; Kotkin 2001; McFaul 2001), similarly to those of some other authoritarian regimes (Przeworski 1991), while the understanding of causes and mechanisms of the new post-Soviet authoritarianism is concentrated solely on structural factors and constraints? In a broader sense, the reliance upon structure-driven approaches tends to explain continuity rather than change, and this state of the field may reflect the existing dismal consensus among scholars instead of setting a new research agenda.

The task of this article is twofold. It aims to refocus the analysis of post-Soviet regime dynamics and add an agency-driven perspective in explaining the logic of political trajectories. This will also allow scholarship to move beyond the dismal consensus on Russia and reconsider the sources and mechanisms of political changes in a more systematic way. This is why I will propose different models of political regime dynamics in post-authoritarian settings and then discuss the effects of changes in structural variables, and of the unintended consequences of the incentives and choices of self-interested political actors, who are not omnipotent and well-informed strategists. The limited predictive capacity of both political actors and political analysts leaves some "bias for hope" in the analysis of regime dynamics, thus challenging the dismal consensus as a way of thinking in post-Soviet Eurasia and beyond.

\section{Two political models: "Lord of the Flies" versus "pluralism by default"}

Perhaps the best-ever description of post-Soviet regime dynamics in Russia was published as early as 1954 - not in political science, but in fiction. Nobel Prize winner William Golding's Lord of the Flies is worth reading as a classic example of authoritarian regime-building on an uninhabited island by a community of teenagers. ${ }^{1}$ According to Golding's plot, political regime dynamics on this island underwent the following stages: (1) a failed attempt to build an electoral democracy; (2) failed informal power-sharing between the most influential actors (an oligarchy); (3) seizure of power by the most brazen teenager, who excluded his rivals from the community, reshuffled the "winning coalition" of followers (Bueno de Mesquita and Smith 2011), and established (4) a repressive tyranny, which resulted in a new 
catastrophe. In the novel, the encroachment of external actors (namely, navy officers) put an end to these dynamics, but in real life, the catastrophe could continue virtually forever. One should admit, however, that Golding's characters were not doomed to tyranny because of unfavorable structural factors: they were just ordinary teenagers, left to their own devices. The major lesson of Lord of the Flies for political scientists is that authoritarianism is a natural logical outcome of the power maximization drive of successful brazen politicians who face insufficient constraints to their aspirations. These constraints may fail to be imposed by other politicians (who may be less impertinent and/or less lucky than their rivals), or by society at large (which may agree that "any order is better than any disorder" [Przeworski 1991, 86] and accept an authoritarian status quo), and/or by external actors (largely absent in the novel's pages until the very end). Such a trajectory of political evolution manifested in the case of post-Soviet Russia and a number of other countries.

In reality, democratization is not a direct consequence of any "prerequisites," but also a result of causal mechanisms, such as elite conflicts, which cannot be resolved as zero-sum games, or bottom-up pressures from mass social movements on the political class, or the external influence of developed democracies. In post-Soviet Russia, however, none of these mechanisms was at work. All elite conflicts were resolved in a zero-sum manner: the dissolution of the Soviet Union in 1991, the elimination of the Congress of People's Deputies in 1993, Boris Yel'tsin's presidential reelection in 1996, and the struggle for Yel'tsin's succession in 1999-2000 (Gel'man 2015). Mass political participation, effectively mobilized during the times of perestroika, was tamed and/or had a limited impact after the Soviet collapse (Robertson 2011; Greene 2014): even some visible episodes of public discontent such as the 2011-2012 wave of mass protests did not significantly change this picture. At the same time, foreign political influence on Russian domestic politics remained weak during the entire post-Soviet period. Unsurprisingly, under these conditions, Russia's rulers were left to their own devices, similar to Golding's teenagers, and thus the trajectory of Russia's political regime demonstrated similar dynamics. The failure of electoral democracy and the rise of oligarchs in the 1990s turned into seizure of power and exclusion of the regime's rivals in the 2000s, and contributed to the consolidation of a personalist authoritarian regime in the 2010s, which tended to rely more systematically upon selective repressions as a tool of political control for the sake of power preservation (Gel'man 2016). At all critical junctures of post-Soviet political development in Russia when politicians had to choose between democratization (in other words, power shifting by electoral means) and preserving power in their own hands, the rejection of democracy became a natural logical move for ruthless self-interested rulers who met insufficient resistance to their aspirations (at least, at the time). One might argue that the rise of post-Soviet authoritarianism in Russia emerged as a side effect of the failure of its democratization after the collapse of communism. Still, the pattern of Lord of the Flies - a unilateral zero-sum seizure of power by the strongest actors-also prevailed in the cases of political regime trajectories in other post-Soviet countries, ranging from Belarus (Way 2015) to Uzbekistan (Jones Luong 2002), even though their post-Soviet critical junctures were less numerous or did not happen at all. Regardless of these variations, the "Lord of the Flies" model results in a nondemocratic equilibrium: once established, it may reproduce over time even despite political leadership changes, as the experience of Turkmenistan and, more recently, of Uzbekistan suggests.

The only alternative to the "Lord of the Flies" model of post-Soviet authoritarian regime building that emerged in post-Soviet Eurasia has been described by Lucan Way as "pluralism by default" (Way 2015). If elite fragmentation is sufficient that one cannot seize power unilaterally, then this fragmented arrangement of actors may prevent power monopolization or, at minimum, impose major barriers to such an outcome of conflicts. Against the background of a fragile stalemate in intra-elite struggles and numerous reshufflings of ad hoc coalitions of oligarchs and local leaders, competing elite segments are 
forced to use the tool of mass mobilization domestically and appeal for support from foreign actors (both pro-democratic and anti-democratic) internationally. These political dynamics were typical for Ukraine and Moldova after the Soviet collapse. ${ }^{2}$ After a series of conflicts and periods of turbulence, in the 2010 s these countries became electoral democracies, but not because of a conscious choice by elites and masses alike. Rather, democratic outcomes occurred in these cases because those seeking to become dominant actors (as per the "Lord of the Flies" model) were unable to seize and monopolize power, and their attempts to use violence against fellow citizens (as Viktor Yanukovych attempted to do in 2014) resulted in loss of power. At least, the chances of the rise of personalist autocracies similar to Russia or Kazakhstan look slim at the moment both in Ukraine and in Moldova, and the institutional empowerment of their legislatures and governments relative to presidents (Hale 2015) has diminished these chances. It is too early to speculate to what extent the continuity of "pluralism by default" over time may turn into a democratic equilibrium of institutionalized competitive politics - at best, the "pluralism by default" model could be described as a "democratic situation" (Collier and Levitsky 1997, 446), but it is hard to judge risks of further disequilibrium.

In essence, the patterns of elite conflicts (zero-sum versus non-zero-sum) make for a major (if not the only) source of difference between the "Lord of the Flies" and "pluralism by default" models of political regime dynamics. As Mancur Olson stated, "Autocracy is prevented and democracy is permitted by the accidents of history that leave a balance of power or stalemate-a dispersion of force and resources that makes it impossible for any one leader or group to overpower all of the others" (Olson 1993, 573). Arrangements of domestic elites served as the key actor-driven variable, while both mass actors and international pro-democratic and anti-democratic "leverages" (Levitsky and Way 2010) played at best a secondary role in determining these outcomes. The impact of mass political participation in building barriers against possible seizure and monopolization of political power may be considered a side effect of intra-elite struggles. Moreover, as Graeme Robertson convincingly explained in his analysis of labor protests in Russia in the 1990s, mass unrest served to provide bargaining chips for resolving intra-elite conflicts between national and subnational leaders, and their elite-driven mobilization or demobilization was largely instrumental (Robertson 2011). In a similar way, Scott Radnitz also portrayed certain episodes of political mobilization in Central Asia as "weapons of the wealthy" (Radnitz 2012): the impact of mass politics is complementary but not substitutive to non-zero-sum elite conflicts. The same might be true for analysis of the democratizing effects of international influence vis-à-vis domestic political struggles: the reliance of domestic political actors upon the support of Western democratizers (as well as upon the support of anti-democratic "black knights") is largely instrumental and can strengthen (or weaken) domestic political competition but cannot impose (or eliminate) it from outside.

To put it bluntly, the political regime dynamics in the entire region of post-Soviet Eurasia over the last quarter century fit one or the other of these two types of political trajectories- "Lord of the Flies" or "pluralism by default" - although some cases, such as those of Georgia or Armenia (Derluguian 2017), have demonstrated inconsistent oscillations between them. In this respect, one should admit that the "pluralism by default" model is by no means affected by socio-economic structural factors to a greater degree than that of "Lord of the Flies." The same gap can be observed with regard to their effects: economic growth and development in Ukraine as well as its quality of governance are at least no better (if not worse) than those in Russia. In a sense, these trends challenge the conventional argument about the key role of socio-economic development as a necessary, if not sufficient, factor of democratization (as in the classical version of the structural approach). 
Shifting the lenses of scholarly analysis of post-Soviet political regime dynamics back from structure to agency may lead to similar conclusions to previous agency-driven accounts of regime changes, those made during the "third wave" of democratization (Huntington 1991). As Adam Przeworski considered "democracy as a contingent outcome of conflicts" (Przeworski 1988, 59), one can treat the rise of authoritarianism in post-Soviet Eurasia and beyond as a contingent outcome of intra-elite conflicts as well. In many ways, post-Soviet non-democratic countries were (and still are) not doomed to establish personalist authoritarian regimes once and forever, even though the chances of their democratization currently look unpromising, to put it mildly. However, this shift of lenses is important not only in political but also in scholarly terms.

\section{How and why actors matter}

The current dismal consensus among scholars over prospects for democracy and democratization in the world (and especially in post-Soviet Eurasia) is not entirely new. To a large degree, it looks like a replica of the dismal consensus of the 1970s. This was the time when the negative consequences of the Vietnam War and Watergate were considered major threats to the Western world much more than Brexit and Trump are today, when the dead end of stagflation was perceived as a predictor of the coming decline if not complete collapse of capitalism, and when almost nobody believed that communism would end relatively soon. Quite the opposite, the gloom over the very possibility of democratization of authoritarian regimes was much deeper than today-the prospect was called into question, if not completely denied (Huntington 1984). During these years, major scholars published alarmist reports about the irresolvable global crisis of democracy, and structural determinism dominated in skeptical accounts of the future of political freedoms in developing countries (Crozier, Huntington, and Watanuki 1975) — all things that sound much too familiar to present-day observers. At the same time, long-standing authoritarian regimes coming to an end in Portugal and Spain, and the subsequent major collapse of nondemocracies in Latin America and, later on, in Eastern Europe during the next decade could hardly have been predicted. This was also the time when the most influential actor-centered research project was launched in 1979 under the auspices of the Woodrow Wilson Center, and in seven years, it culminated in the oft-cited four-volume set, Transitions from Authoritarian Rule (O'Donnell, Schmitter, and Whitehead 1986).

Many years later, Guillermo O'Donnell recalled the scholarly point of departure of the "Transitions" project as the following:

... we found this [structural-V.G.] perspective rather dismal, so we thought to emphasize political factors, purposive political actions, and show how politics could counteract or activate these slowly moving structural factors. We also had the notion ... that the impact of structural variables on behavior is not a constraint but itself is variable. (Munck and Snyder 2007, 292)

[no new paragraph]This argument is worth reconsidering in light of recent political regime dynamics across the globe, including post-Soviet Eurasia. Even though the scholars of the "Transitions" project were pro-democratic sympathizers and their refocusing on the key role of agency was driven by a disagreement with the structure-induced notion of a durable authoritarian status quo, they did not deny the structural perspective as such but reformulated the impact of structural factors. ${ }^{3}$ The actor-based perspective added a necessary dynamic dimension to the largely static picture of political regimes, which at that time was merely perceived as a projection of economic development, social structure, and/or 
cultural traits. Although the "Transitions" project developed a "dynamic model" (Rustow 1970) of regime changes occurring in a democratic direction, the framework for analysis was one that had been proposed a little earlier for another large-scale project studying democratic breakdowns (Linz and Stepan 1978), based on somewhat similar conceptual and methodological principles. To summarize, agencydriven analyses with their emphasis on micro-level moves of political actors, often formalized through the prism of a rational choice approach and game-theoretical models (Przeworski 1991; Colomer 2000), offered a welcome complementarity rather than substitution for macro-level structural explanations (Mahoney and Snyder 1999).

These lessons from the dismal consensus of the 1970s and how it was overcome over the next decadeboth in political and in scholarly terms - may be useful for reassessment of the current state of the field in research on post-Soviet regime dynamics and its further prospects. It is an important exercise given the recent boom in studies of Russian politics in the United States (Frye 2017), which is driven not only by ongoing tensions in US-Russian relations ${ }^{4}$ but also by the increasing interest of political scientists in comparative studies of authoritarianism (Gandhi 2008; Levitsky and Way 2010; Bueno de Mesquita and Smith 2011; Svolik 2012). Still, the dismal consensus in research on post-Soviet Eurasia is reproduced over and over again, in part because of the echo-chamber effect among analysts of contemporary politics, who tend to reinforce each other's frustrations and biases beyond the needs of the field. Meanwhile, the need for a new "dynamic model" of post-Soviet political regimes instead of the present-day dismal consensus is vitally important for further development of a research agenda and may have implications beyond the region of Eurasia.

Following O'Donnell's comments on the impact of structural variables (economic and non-economic alike) on political regime dynamics, it is possible to revisit not only scholarship's understanding of them but the basic list itself. These variables should be considered as ever-changing environmental conditions of political regime dynamics, which may evolve over time in different directions because of the effects of many other variables. In particular, several non-economic structural factors of political regime dynamics, such as the use of coercive power by states, mobilization of identity divisions (or lack thereof), and the effects of various "legacies of the past" may be not only be considered causes of the diversity of trajectories of political regimes (Hale 2015; Way 2015), but also perceived as effects of strategic moves taken by political actors.

State coercion as a repressive instrument of political regimes (Davenport 1995) is essential for the survival of autocracies, and this is why this perspective of analysis of post-Soviet state-building is very important for an understanding of the successes and failures of authoritarianism (Levitsky and Way 2010; Way 2015). Still, the question is to what extent various outcomes of repressive policies were determined by structural causes or, rather, to what extent they were driven by the efforts of post-Soviet political leaders. While almost all of them invested certain efforts in the building of hierarchical "power pyramids" (Hale 2015) within the state apparatus, known in Russian political jargon as the "power vertical," their effects were different despite certain similarities among their Soviet-era building blocks. In Belarus, Alexander Lukashenko effectively developed "preemptive" authoritarianism (Silitski 2005) despite a lack of structural prerequisites. His regime systematically exploited the state's control over the economy, and combined comprehensive top-down control and monitoring of all activities with an open border and strong incentives for emigration by real and/or potential dissenters (Way 2015; Gel'man 2016), thus preventing any serious risks of mass protests. In Russia, Putin during his first two presidential terms very successfully pursued the recentralization of the state after its deep and protracted decentralization. He was able to reintegrate subnational "political machines" into a nationwide vote delivery reserve force 
through effective institution-building (Reuter 2017) and offering a winning combination of sticks and carrots to the subnational layers of the "power vertical" (Gel'man and Ryzhenkov 2011). Thus, the Kremlin provided sufficiently strong incentives for the political loyalty of its subordinates and extended it from the level of regions and cities (Reuter and Robertson 2012) to the level of enterprises (Frye, Reuter, and Szakonyi 2014). In the end, Russia's regime successfully coped with the unexpected wave of mass protests in 2011-2012 (Gel'man 2015) and further tightened the screws of repressive policies.

By contrast, during his reign Ukrainian president Yanukovych completely failed to build a power vertical before the Euromaidan protests (Kudelia 2014). Instead of investing in authoritarian institution-building and turning the coercive apparatus into an effective instrument of control over the state machinery, Yanukovych staffed subnational executive offices with his personal loyalists, thus increasing the alienation of many local leaders and oligarchs. The latter, having retained relative political and economic autonomy, later betrayed the autocrat after his fall (other than in Yanukovych's own solid power base in Donbas) (Fisun 2015). Yanukovych was also very inconsistent in the use of repressions before and during the Euromaidan crisis, and applied violence against the opposition only when the scope of protests exceeded the technical capabilities of coercion, rather than relying upon the preemptive strategies of his counterparts in Belarus and Russia. Judging by these preliminary comparisons, one might argue that "success stories" of rebuilding state coercion in Belarus and Russia and the story of failure of state coercion in Ukraine to a large degree should be attributed to agency-driven rather than structure-induced factors: Lukashenko and Putin co-opted the followers and isolated the rivals of their political regimes, thus extending "winning coalitions" (Bueno de Mesquita and Smith 2011), while Yanukovych did exactly the opposite.

The same argument may be applied to evaluations of the authoritarian effects of numerous "legacies of the past," which are often perceived generally, but especially in Russia and Eurasia, as eternal barriers to democracy and good governance (Hedlund 2005). There, the legacy of the past is loosely understood as a set of historically established obstacles to democratization, which emerged before the Soviet collapse for various reasons and has persisted for an indefinite period. However, this deterministic perception of a "legacy" fails to explain why it has a different impact on different countries and policy areas, and how exactly it affects post-Soviet institutions and practices. Instead of discussing arguments of path dependency over and over again, one may pay more attention to the causal mechanisms of the translation of legacies into the political and policy agenda for today and tomorrow. In search of alternatives to determinism, Stephen Kotkin and Mark Beissinger redefined "legacy" as "a durable causal relationship between past institutions and policies on subsequent practices or beliefs, long beyond the life of the regimes, institutions, and policies that gave birth to them" (Kotkin and Beissinger 2014, 7). They also outline several causal mechanisms for transferring these institutions and practices from the past to the present and the future, including material ("parameter-setting"), organizational and institutional ("fragmentation" and "translation"), and ideational ("cultural schemata"). "Parameter-setting" relates to the foreclosure of certain institutional and/or policy choices due to material constraints left over from the past; "fragmentation" involves the direct inheritance of whole parts of previous institutions from the old regime, while "translation" means using old institutions for new purposes; and "cultural schemata" refer to perceptions generated by past regime practices that make certain forms of conduct either normal or unacceptable (Kotkin and Beissinger 2014, 16).

Although this typology is useful, it is also worth mentioning that only one of these mechanisms, namely parameter-setting, is essentially structural by nature - it results from certain limits set by the physical and technological infrastructure inherited from the Soviet past, which posed major barriers to structural 
reforms in the economy (Gaddy 2014). All other mechanisms of translation of legacies into the presentday agenda, and their maintenance as cornerstones of authoritarianism in post-Soviet Eurasia are largely agency-driven, in the manner of social constructs, which are created and maintained by ruling groups for the sake of power maximization (Gel'man 2017). One might argue that various legacies of the past affect the present and the future mostly because of the means by which they are transferred. The intentional use of Soviet institutions and practices as a set of building blocks for post-Soviet institution-building and mechanisms of governing states and regimes contributed to preservation of the authoritarian status quo through fragmentation or translation of this social construct into major political choices and solutions. Examples include the transformation of government structure after the Soviet collapse with regard to performance of the state apparatus (Huskey 2014), and practices of control and monitoring in law enforcement agencies (Taylor 2014), both of which extended the lives of outdated institutions and organizations, thus contributing to a lack of political accountability and to the use (or abuse) of the state agencies and coercive apparatus of post-Soviet states as instruments of political regimes and their leaders. In this respect, "cultural schemata," modes and patterns of thinking and perceiving reality, are especially relevant for uncovering the agency-driven logic of post-Soviet authoritarian regime building. These models and patterns were embedded in the past, but outlived it and gave birth to the new post-Soviet normative ideal, which could be roughly labeled a "good Soviet Union" (Gel'man 2017), the basis for a "mental model" (Denzau and North, 1994) for post-Soviet elites and societies.

In the case of ideational legacies, "history matters" as long as actors are able to use it purposively to achieve their goals in various areas, including maintaining political regimes. The time horizon for these reflections cannot be indefinitely long. In post-Soviet Eurasia, it is relevant to the recent life experience of one or two generations, who, correctly or otherwise, interpreted the Soviet collapse and post-Soviet political and economic changes as a major trauma and framed their perceptions of the late Soviet experience as a paradise lost. When it comes to the mechanisms for bringing legacies into the current agenda, material, organizational, and institutional legacies impose high costs on further regime changes and contribute to the preservation of the political status quo. However, the scale of these costs may decrease over time because of the emergence and spread of new institutions and practices not embedded in the past. Meanwhile, ideational legacies define the understanding of the means and possible goals of the process of institution-building, and serve as tools of ruling groups in this process.

In essence, the legacies of the past are largely a socially constructed phenomenon in post-Soviet Eurasia and beyond, and should be regarded not as a structural constraint but as an agency-driven phenomenon. With regard to political regimes, cultural schemata work as instruments for maintaining authoritarian equilibrium because they establish a retrospective vector of public discussion, where the Soviet past is considered as the main (if not only) "point of departure." History is not only a subject for historians, but penetrates all aspects of public life in the region. The imagined past experience has become a normative marker in projecting the future of post-Soviet Eurasia, including political regimes. The "good Soviet Union," an imagined politico-economic order that somehow resembles that of the Soviet past while lacking its inherent flaws, in reality bears little resemblance to the late Soviet experience. Elements of the Soviet legacy are selectively and deliberately chosen for the sake of the power maximization of the post-Soviet ruling groups. They include the hierarchy of the power vertical, "cadre stability" at all levels of government (that is, low elite circulation), a closed recruitment pool of elites and their formal and informal privileged status, state control over major media, state repressions toward organized dissent, and so on. Meanwhile, other elements of the late Soviet politico-economic order, such as relatively low inequality and certain state social guarantees, have been discarded without meaningful resistance. In addition, the "good Soviet Union" includes certain features that did not exist in the real Soviet Union but 
are very important for ruling groups: not only a fully fledged market economy and no shortages of goods and services, but also a lack of institutional constraints on rent-seeking and the creation of an external interface for legalization of incomes and status abroad (Cooley and Heathershaw, 2017). The assertion that the "good Soviet Union" is a deliberate construction by post-Soviet ruling groups and their entourages is no wild exaggeration: in the 2000s, against the background of post-transformation economic growth, they acquired that which they wanted but which had been unavailable to their late Soviet predecessors, and their efforts to preserve this normative ideal have borne fruit in many ways. As a result, the "good Soviet Union" has not produced incentives to overcome authoritarianism but has become a successful instrument for the legitimation of the political status quo at least in the mediumterm perspective, until the current generation of post-Soviet rulers and citizens leave the public scene (Gel'man 2017).

Last but not least, political identity and its mobilization for the overthrow of post-Soviet authoritarian regimes (Way 2015) as well as for their preservation (Rogov 2015) is a by-product of a social construction to an even larger degree than the normative ideal of a "good Soviet Union." Its political uses may be considered as by-products of intra-elite struggles, and the zero-sum resolution of these conflicts leaves little room for alternative anti-regime identities: they either become co-opted into regime-led "winning coalitions" or are successfully marginalized. Russia may serve as an example of both outcomes. On the one hand, ethnic and regional identities that had been successfully politically mobilized in the 1990s by subnational elites (Gorenburg 2003) in the 2000s lost their salience because of the political weakening of these elites and their integration into the power vertical (Goode 2011). On the other, the potential of the civic and cultural identities that became so visible during the wave of mass protests in 2011-2012 has been diminished in the wake of regime-initiated campaigns of "cultural wars" (Smyth and Soboleva 2014; Robinson 2017). At the same time, where such struggles have non-zero-sum outcomes, foreign policy identities can be effectively mobilized, as the experiences of Ukraine and Moldova suggest (Way 2015). Again, this phenomenon can be considered not as a cause of political regime dynamics but rather as its effect, both in post-Soviet Eurasia and elsewhere.

To summarize, bringing actors back into the analysis of post-Soviet regime dynamics has not only challenged the emphasis on the role of non-economic structural factors in explaining these trajectories but in a way provided a completely different picture. State coercion, legacies, and identities are driven to a large degree by the interests and choices of power-maximizing political actors, and the outcomes of their conflicts often matter more than these factors themselves. The shift in research focus may help to explain why in some countries these factors are important for their political regime dynamics whereas in others they are not. These considerations are also relevant to establishing the next research task.

\section{In search of a new dynamic model}

The other feature of the dismal consensus among scholars of post-Soviet Eurasia is its implicit assumption of the persistence of current political regimes for an indefinitely long period. For the "pluralism by default" model, the main expectation is the continuity of "muddling through" without serious progress toward sustainable democracy or sustainable authoritarianism, while the "Lord of the Flies" model implies that an autocrat who has seized and usurped power will remain invincible until his death. While this assumption may be correct in factual terms, it has left little room for analysis of sources of further political regime changes, to some extent resembling the failures of Sovietologists during the period of dismal consensus in the 1970s. 
At first sight, the structural factors of the present day offer low odds of democratization in post-Soviet Eurasia and beyond. The international environment currently looks rather unfavorable for the prevention of autocracy (let alone permission of democracy), similar to the age of the 1970s dismal consensus. One might further compare the consequences of the financial crisis of 2008-2009 for Europe with the somewhat similar effects of the 1970s stagflation in the West. In that light, it is no wonder that in the eyes of many politicians, democracy means instability if not chaos, and with the authoritarian drift of numerous countries ranging from Hungary to Turkey, democracy looks even less appealing. The prospects for sustainable economic growth in Russia and certain other post-Soviet countries are dubious at best, especially after the end of the oil boom of the 2000s. But will these conditions be long lasting, and how might they affect the preservation of the political status quo? At the same time, the inevitable aging of the political leaders in post-Soviet personalist authoritarian regimes may increase risks of disequilibrium. These risks are fueled by the low chances for hereditary leadership succession in these regimes (Brownlee 2007), ${ }^{5}$ and the success story of the dynastic rule of the Aliyev family (Hale 2015) may remain exceptional in post-Soviet Eurasia. Furthermore, the inevitable process of generational change among the mass public is likely to increase these risks due to the rising demands for alternatives to the political status quo among the Russian youth, and the major disconnect between their way of life and that of their grandparents' generation, who tend to rule the country without using the Internet, and perceive it as a source of political threats (Soldatov and Borogan 2015). In addition, the attractiveness of the "good Soviet Union" as a retrospective normative ideal for Russia and Eurasia will decrease over time despite propaganda efforts.

In fact, the "Lord of the Flies" model could transform into a new edition of The Autumn of the Patriarch, increasing the risks of disequilibrium very similarly to the personalist rule of an aging dictator so brilliantly described by Gabriel Garcia Marquez. In particular, in Russia the features of the political trajectory that became visible after the annexation of Crimea-the rejection of economic modernization and the abandonment of the very goal of growth and development, a reactionary domestic agenda based on "the politics of fear" (Gel'man 2016) and "cultural wars" (Robinson 2017), and desperate attempts to restore Russia's status as one of the global "oligarchs" in foreign policy at any cost-are likely to persist over time as Putin's rule continues. Not only may domestic and international perceptions of the aging leadership as a threat increase over time, but the previous experience of regime survival after aggressive responses to earlier threats (Davenport 1995) may also contribute to the temptation to use the same political tools repeatedly, often in an unpredictable and self-destructive manner.

Disequilibrium of authoritarian regimes, however, does not necessarily result in democratization, as about $70 \%$ of cases of authoritarian breakdowns after World War II led to the replacement of one form of authoritarianism by another (Geddes, Wright, and Franz 2014). The countries of post-Soviet Eurasia may follow this path if new elite conflicts are resolved in a zero-sum manner, thus repeating the same "Lord of the Flies" scenario. However, one should take into account the original context of the 1990s, when the zero-sum resolutions of intra-elite conflicts in Russia, Belarus, or Azerbaijan were deeply affected by the numerous consequences of the Soviet collapse, such as the decline of law and order, ethnic conflicts, and the deep and protracted transformation recession in the economy. In a sense, the rise of certain post-Soviet authoritarian regimes was a side effect of the failed attempts at the democratization of the Soviet Union under Mikhail Gorbachev and later of Russia under Yel'tsin (Gel'man 2015). However, it is highly unlikely that similar combinations of factors will occur simultaneously in several countries of the region decades later, and thus contribute to a second fall into the same trap. 
Scholars lack a magic bullet for the invention of a new comprehensive explanatory actor-centered dynamic model of political regime changes in post-Soviet Eurasia and beyond, let alone for building its predictive capacity. Some of the hints already gained, however, will be useful. The first and foremost of these is the major shift from normative to positive lenses of analysis of political regimes, which will enable scholarship to overcome the Manichean dichotomy of "democracy versus authoritarianism" and avoid both Hollywood movie and film noir thinking about politics in post-Soviet Eurasia and elsewhere. Politicians cannot be defined as either "good guys" or "bad guys," but rather as self-interested opportunists who seek power maximization and make certain choices in order to achieve their goals. In given circumstances, they may opt for democracy or authoritarianism, but not because they are strongly committed to either of these regimes in ideational terms (as has often been assumed by scholars since the times of the "Transitions" project) ${ }^{6}$ but because of their expectations of the costs and benefits of their choices. Moreover, some post-Soviet politicians may change sides over time and contribute both to authoritarian regime-building and to its demise. Petro Poroshenko in Ukraine might be a prime example of such behavior. He was (and still is) a wealthy oligarch, and he joined the "winning coalition" around Viktor Yushchenko before the Orange Revolution of 2004, then switched sides and served as a minister during the reign of Yanukovych, but in 2013-2014 became the main sponsor of the Euromaidan protests and, in the end, their major beneficiary, being elected as Ukrainian president in May 2014. No wonder that Poroshenko as a president has little incentive to pursue much-needed political and policy reforms in Ukraine (Hale and Orttung, 2016), which may hurt his political and business interests. Blaming politicians for such inconsistent behaviour is similar to blaming dolphins for eating fish.

The shift from normative to positive lenses of analysis is also useful in practical terms for balancing the research focus. While some analysts considered the recent waves of regime changes in post-communist countries to be successes of a pro-democratic and pro-Western opposition (Bunce and Wolchik 2011), their critics noted that these developments resulted from the failure of their authoritarian rivals (Way 2015). However, these discussions of "who is to blame" for the survival or collapse of authoritarianismthe regime or the opposition-have paid little attention to the strategic interactions between and within these two groups of actors as players of the same (repeating) game of political regime dynamics. Doing so would diminish the risk of disillusionment among scholars and experts regarding certain unfulfilled promises of democratic breakthroughs, especially in cases of "pluralism by default." It must be said that the failure of authoritarian drift (as in Ukraine under Yanukovych) has not led to democracy by default. This is not only because "democracy is a system where parties lose elections" (Przeworski 1991, 10) and politicians tend to use various tricks to avoid power shifts by electoral means; the experience of postSoviet Russia is telling in this respect (Gel'man 2015; Golosov 2017). It is also because the development of democracy becomes irreversible only if it provides conditions for a major turnover of ruling elites, rather than their cartel-like agreements on the partial reshuffling of "winning coalitions," as in Ukraine or Moldova (Hale 2015). As Neil Abrams and M. Steven Fish convincingly demonstrated in their analysis of the success story in Estonia, these conditions became the key for that country's advancement (Abrams and Fish 2015). Still, most post-Soviet political actors lack incentives for building democracy and this is why in cases of "pluralism by default" they may at best prevent authoritarianism: under these conditions, in Olson's terms, democracy is "permitted," but not necessarily practiced. Moreover, the recent experience of the undermining of democratic practices in certain post-communist countries of Eastern Europe, such as Hungary (Magyar 2016), has only reinforced these caveats.

Taking a positive research perspective (instead of the normative one) may also help to diminish risks of excessive hopes for democratic potential to overthrow autocrats and, more importantly, of excessive demonization of authoritarian leaders. This is especially true in the case of Putin, often portrayed by 
scholars and analysts as an omnipotent and invincible super-powerful actor that resembles characters from spy movies if not crime novels (Dawisha 2014; Hill and Gaddy 2013). Of course, one should definitely not underestimate the political effects of authoritarian learning in post-Soviet Eurasia (Hall and Ambrosio 2017; Golosov 2017), nor the capabilities and skills of autocrats elsewhere across the globe (Bueno de Mesquita and Smith 2011). Yet authoritarian leaders are vulnerable to numerous strategic miscalculations and tactical errors despite (or perhaps because of) the greater degree of freedom in their choices and tactics vis-à-vis their democratic counterparts. The sad experience of Yanukovych, who ruined his "winning coalition" before and during the Euromaidan protests (Kudelia 2014), demonstrates a chain of fatal errors made by a ruler who faced unexpected challenges and failed to respond appropriately. In a broader sense, information problems, which are typical for many authoritarian regimes (Svolik 2012), may increase this vulnerability under conditions of disequilibrium: the unintended consequences of moves made by political actors may make those moves self-destructive.

The problem for scholars of political regime dynamics in post-Soviet Eurasia and beyond is not only their own limited predictive capacity in a changing environment but also the very long list of unknown variables that may be crucial for understanding regime trajectories. This list includes, among others, the readiness of post-Soviet authoritarian regimes, where they perceive threats to their survival, to employ large-scale political violence as a primary tool of dominance, instead of relying upon small-scale preemptive repressions domestically (Silitski 2015; Gel'man 2016) and "proxy wars" internationally. Another very important and yet unknown variable is the dynamics of mass political support, which may change dramatically if alternatives to the political status quo are perceived as viable. The observed high degree of support for political leaders, even if it is genuinely representative in non-competitive conditions (Frye et al. 2017), may decline under conditions where real political choices are available. In addition, the degree of governability of post-Soviet states, notorious for their practices of bad governance (Gel'man 2017) is also unknown: scholars and experts do not know how these states may respond to possible exogenous shocks of various kinds, or how these responses may or may not affect political regime dynamics.

This long list of unknown variables makes analyzing the rationale of political changes (let alone their prediction) highly problematic, especially in cases of falling autocrats, as in Ukraine in 2014. However, understanding the limits and boundaries of scholarly knowledge is a necessary step toward breaking the dismal consensus and instead searching for new models of political regime dynamics. This shift in conceptual frames will help analysts of post-Soviet Eurasia to "think possibilistically, not probabilistically," as Philippe Schmitter summarized it in the context of the "Transitions" project (Munck and Snyder 2007, 324). Indeed, the logic of political changes, especially under an autocracy, is highly non-linear, as the experience of the collapse of many authoritarian regimes suggests. Tipping points often occur not only due to sudden shifts in public opinion, when alternatives to dictatorships emerge (Kuran 1991), but also due to changes in coalition dynamics among the elites (Svolik 2012). The possibilistic shift in thinking about politics may also offer some sort of bias for hope to those scholars who still believe in democracy and democratization in the region and beyond despite all the anti-democratic challenges and temptations around the globe. This is why the main slogan of the Russian opposition rallies- "Russia Will Be Free!"- may be perceived not just as a call for action but also as a key item on the political agenda in the not so distant future.

\section{Acknowledgements}


A previous version of this paper was presented at the conference "Critical Issues in the Research of Contemporary Russian Politics" (University of Helsinki, June 2017). I would like to thank Oleksandr Fisun, Timothy Frye, Henry Hale, and Kirill Rogov for their very useful comments on earlier versions of the text.

\section{Funding}

This article is part of the Center of Excellence "Choices of Russian Modernization," funded by the Academy of Finland (grant No.284664).

\section{Notes}

1. This parallel was first drawn by Samuel Huntington $(1965,416)$

2. To some extent, the case of Kyrgyzstan is also close to the "pluralism by default" trajectory (Radnitz 2012).

3. O'Donnell himself, with his earlier concept of "bureaucratic authoritarianism" in Latin America (O'Donnell 1973), might be a prime example of a scholar working from such a perspective; the same is true for Fernando Henrique Cardoso, Adam Przeworski, Philippe Schmitter, and Alfred Stepan; the "Transitions" project become a refocusing rather than a rejection of the previous research agenda.

4. The slogan "know your enemy," a major driver of Soviet studies during the Cold War (Engerman, 2009), has not lost its relevance.

5. The post-Soviet elites' strong awareness of these prospects provides them with strong incentives to behave as "roving bandits" (Olson 1993) and greatly contributes to various instances of bad governance (Cooley and Heathershaw 2017; Gel'man 2017).

6. Ideational factors played a comparatively negligible role in post-Soviet politics (Hanson 2010; Hale 2015) - most probably because of the political learning effect after the failure of Gorbachev, who was a true believer in the renewal of socialism.

\section{References}

Abrams, N., and M.S. Fish. 2015. "Policies First, Institutions Second: Lessons from Estonia's Economic Reforms." Post-Soviet Affairs 31 (6): 491-513.

Brownlee, J. 2007. “Hereditary Succession in Modern Autocracies.” World Politics 59 (4): 595-628.

Bueno de Mesquita, B., and A. Smith. 2011. The Dictator's Handbook: Why Bad Behavior Is Almost Always Good Politics. New York: Public Affairs.

Bunce, V., and S. Wolchik. 2011. Defeating Authoritarian Leaders in Postcommunist Countries. Cambridge: Cambridge University Press.

Collier, D., and S. Levitsky. 1997. "Democracy with Adjectives: Conceptual Innovations in Comparative Research." World Politics 49 (3): 430-451.

Colton, T. 2017. "Paradoxes of Putinism.” Daedalus 146 (2): 8-18. 
Colomer, J. 2000. Strategic Transitions: Game Theory and Democratization. Baltimore: Johns Hopkins University Press.

Cooley, A., and J. Heathershaw. 2017. Dictators without Borders: Power and Money in Central Asia. New Haven, CT: Yale University Press.

Crozier, M., S.P. Huntington, and J. Watanuki. 1975. The Crisis of Democracy: Report on the Governability of Democracies to the Trilateral Commission. New York: New York University Press. http://trilateral.org/download/doc/crisis_of_democracy.pdf (accessed October 15, 2017).

Davenport, C. 1995. "Multi-dimensional Threat Perception and State Repressions: An Inquiry into Why States Apply Negative Sanctions.” American Journal of Political Science 38 (3): 683-713.

Dawisha, K. 2014. Putin's Kleptocracy: Who Owns Russia? New York: Simon and Schuster.

Denzau, A., and D.C. North. 1994. "Sharing Mental Models: Ideologies and Institutions." Kyklos 47 (1): 3-31.

Derluguian, G. 2017. Armeniya na vykhode iz postsovetskoi restavratsii: analiz vozmozhnostei [Ending the Post-Soviet Restoration in Armenia: An Analysis of Opportunities]. Moscow: Russkii fond sodeistviya obrazovaniyu i nauke.

Engerman, D.C. 2009. Know Your Enemy: The Rise and Fall of America's Soviet Experts. Oxford: Oxford University Press.

Fisun, O. 2015. “The Future of Ukraine's Neopatrimonial Democracy.” PONARS Policy Memos, no. 394. http://www.ponarseurasia.org/memo/future-ukraine-neopatrimonial-democracy (accessed October 15, 2017).

Frye, T. 2017. "Russian Studies Is Thriving, Not Dying." The National Interest, October 3. http://nationalinterest.org/feature/russian-studies-thriving-not-dying-22547 (accessed October 15, 2017).

Frye, T., S. Gehlbach, K.L. Marquardt, and O.J. Reuter. 2017. “Is Putin's Popularity Real?” Post-Soviet Affairs 33 (1): 1-15.

Frye T., O.J. Reuter, and D. Szakonyi. 2014. "Political Machines at Work: Voter Mobilization and Electoral Subversion in the Workplace." World Politics 66 (2): 195-228.

Fukuyama, F. 1992. The End of History and the Last Man. New York: Free Press.

Gaddy, C.G. 2014. "Room for Error: The Economic Legacy of Soviet Spatial Misallocation." In Historical Legacies of Communism in Russia and Eastern Europe, edited by M.R. Beissinger and S. Kotkin, 52-67. Cambridge: Cambridge University Press.

Gandhi, J. 2008. Political Institutions under Dictatorship. Cambridge: Cambridge University Press. 
Geddes, B., J. Wright, and E. Franz. 2014. "Authoritarian Breakdowns and Regime Transitions: A New Data Set." Perspectives on Politics 12 (2): 313-331.

Gel'man, V. 2015. Authoritarian Russia: Analyzing Post-Soviet Regime Changes. Pittsburgh: University of Pittsburgh Press.

Gel'man ,V. 2016. “The Politics of Fear: How Russia's Rulers Counter Their Rivals.” Russian Politics 1 (1): $27-45$.

Gel'man, V. 2017. "Political Foundations of Bad Governance in Post-Soviet Eurasia: Toward a Research Agenda." East European Politics 33 (4): 496-516.

Gel'man, V., and S. Ryzhenkov. 2011. 'Local Regimes, Sub-national Governance, and the 'Power Vertical' in Contemporary Russia." Europe-Asia Studies 63 (3): 449-465.

Golosov, G.V. 2017. “Authoritarian Learning in the Development of Russia's Electoral System.” Russian Politics 2 (2): 182-205.

Goode, J.P. 2011. The Decline of Regionalism in Putin's Russia: Boundary Issues. Abingdon: Routledge.

Gorenburg, D.P. 2003. Minority Ethnic Mobilization in the Russian Federation. Cambridge: Cambridge University Press.

Greene, S. 2014. Moscow in Movement: Power and Opposition in Putin's Russia. Stanford, CA: Stanford University Press.

Hale, H.E. 2015. Patronal Politics: Eurasian Regime Dynamics in Comparative Perspective. Cambridge: Cambridge University Press.

Hale, H.E., and R.W. Orttung, eds. 2016. Beyond the Euromaidan: Comparative Perspectives on Advancing Reform in Ukraine. Stanford, CA: Stanford University Press.

Hall, S.G.F., and T. Ambrosio. 2017. “Authoritarian Learning: A Conceptual Overview.” East European Politics 33 (2): 143-161.

Hanson, S. 2010. Post-Imperial Democracies: Ideology and Party Formation in Third Republic France, Weimar Germany, and Post-Soviet Russia. Cambridge: Cambridge University Press.

Hedlund, S. 2005. Russian Path Dependence. London: Routledge.

Hill, F., and C.G. Gaddy. 2013. Mr. Putin: Operative in the Kremlin. Washington, DC: Brookings Institution Press.

Huntington, S.P. 1965. "Political Development and Political Decay." World Politics 17 (3): 386-438.

Huntington, S.P. 1984. "Will More Countries Become Democratic?” Political Science Quarterly 99 (2): 193-218. 
Huntington, S.P. 1991. The Third Wave: Democratization in the Late Twentieth Century. Norman: University of Oklahoma Press.

Huskey, E. 2014. "Legacies and Departures in the Russian State Executive." In Historical Legacies of Communism in Russia and Eastern Europe, edited by M.R. Beissinger and S. Kotkin, 111-127. Cambridge: Cambridge University Press.

Jones Luong, P. 2002. Institutional Changes and Political Continuity in Post-Soviet Central Asia: Power, Perceptions, and Pacts. Cambridge: Cambridge University Press.

Kotkin, S. 2001. Armageddon Averted: Soviet Collapse, 1970-2000. Oxford: Oxford University Press.

Kotkin, S., and M.R. Beissinger. 2014. "The Historical Legacies of Communism: An Empirical Agenda." In Historical Legacies of Communism in Russia and Eastern Europe, edited by M.R. Beissinger and S. Kotkin, 1-27. Cambridge: Cambridge University Press.

Kudelia, S. 2014. “The House That Yanukovych Built.” Journal of Democracy 25 (3): 19-34.

Kuran, T. 1991. "Now Out of Never: The Element of Surprise in the East European Revolution of 1989." World Politics 44 (1): 7-48.

Ledeneva, A.V. 2013. Can Russia Modernise? Sistema, Power Networks, and Informal Governance. Cambridge: Cambridge University Press.

Levitsky, S., and L.A. Way. 2010. Competitive Authoritarianism: Hybrid Regimes after the Cold War. Cambridge: Cambridge University Press.

Linz, J.J., and A. Stepan, eds. 1978. The Breakdown of Democratic Regimes, 3 vols. Baltimore: Johns Hopkins University Press.

Lipset, S.M. 1959. "Some Social Requisites for Democracy: Economic Development and Political Legitimacy." American Political Science Review 53 (1): 69-105.

Magyar, B. 2016. Post-Communist Mafia State: The Case of Hungary. Budapest: Central European University Press.

Mahoney, J., and R. Snyder. 1999. "Rethinking Agency and Structure in the Study of Regime Changes." Studies in Comparative International Development 34 (2): 3-32.

McFaul, M. 2001. Russia's Unfinished Revolution: Political Change from Gorbachev to Putin. Ithaca, NY: Cornell University Press.

Munck, G.L., and R. Snyder. 2007. Passion, Craft, and Method in Comparative Politics. Baltimore: Johns Hopkins University Press. 
Novokmet, F., T. Piketty, and G. Zucman. 2017. "From Soviets to Oligarchs: Inequality and Property in Russia, 1905-2016." WID.world Working Paper Series, no. 2017/09. http://piketty.pse.ens.fr/files/NPZ2017WIDworld.pdf (accessed October 15, 2017).

O’Donnell, G. 1973. Modernization and Bureaucratic Authoritarianism: Studies in South American Politics. Berkeley: University of California, Institute of International Studies.

O’Donnell, G., P.C. Schmitter, and L. Whitehead, eds. 1986. Transitions from Authoritarian Rule: Prospects for Democracy, 4 vols. Baltimore: Johns Hopkins University Press.

Olson, M. 1993. "Dictatorship, Democracy, and Development." American Political Science Review 87 (3): $567-576$.

Przeworski, A. 1988. "Democracy as a Contingent Outcome of Conflicts." In Constitutionalism and Democracy, edited by J. Elster and R.Slagstad, 59-80. Cambridge: Cambridge University Press.

Przeworski, A. 1991. Democracy and the Market: Political and Economic Reforms in Eastern Europe and Latin America. Cambridge: Cambridge University Press.

Radnitz, S. 2012. Weapons of the Wealthy: Predatory Regimes and Elite-Led Protests in Central Asia. Ithaca, NY: Cornell University Press.

Remington, T.F. 2011. The Politics of Inequality in Russia. Cambridge: Cambridge University Press.

Reuter, O.J. 2017. The Origins of Dominant Parties: Building Authoritarian Institutions in Post-Soviet Russia. Cambridge: Cambridge University Press.

Reuter, O.J., and G.B. Robertson. 2012. "Subnational Appointments in Authoritarian Regimes: Evidence from Russian Gubernatorial Appointments.” Journal of Politics 74 (4): 1023-1037.

Robertson, G.B. 2011. The Politics of Protest in Hybrid Regimes: Managing Dissent in Post-Communist Russia. Cambridge: Cambridge University Press.

Robinson, N. 2017. "Russian Neopatrimonialism and Putin's 'Cultural Turn'.” Europe-Asia Studies 69 (2): $348-366$.

Rogov, K. 2015. "Krymskii sindrom: mekhanizmy avtoritarnoi mobilizatsii [The Crimean Syndrome: Mechanisms of Authoritarian Mobilization]." Kontrapunkt, no. 1. http://www.counter-point.org/wpcontent/uploads/2015/09/rogov_countepoint1.pdf (accessed October 15, 2017).

Ross, M.L. 2012. The Oil Curse: How Petroleum Wealth Shapes the Development of Nations. Princeton, NJ: Princeton University Press.

Rustow, D. 1970. “Transition to Democracy: Towards a Dynamic Model.” Comparative Politics 2 (3): 337-363.

Silitski, V. 2005. "Preempting Democracy: The Case of Belarus." Journal of Democracy 16 (4): 83-97. 
Smyth, R. and I. Soboleva. 2014. 'Looking beyond the Economy: Pussy Riot and the Kremlin's Voting Coalition." Post-Soviet Affairs 30 (4): 257-275.

Soldatov, A., and I. Borogan. 2015. The Red Web: The Struggle between Russia's Digital Dictators and the New Online Revolutionaries. New York: Public Affairs.

Solnick, S.L. 1998. Stealing the State: Control and Collapse in Soviet Institutions. Cambridge, MA: Harvard University Press.

Svolik, M. 2012. The Politics of Authoritarian Rule. Cambridge: Cambridge University Press.

Taylor, B. 2014. "From Police State to Police State? Legacies and Law Enforcement in Russia." In Historical Legacies of Communism in Russia and Eastern Europe, edited by M.R. Beissinger and S. Kotkin, 128-151. Cambridge: Cambridge University Press.

Travin, D. 2016. Prosushchestvuet li putinskaya sistema do 2042 goda? [Will Putin's System Survive until 2042?]. St. Petersburg: Norma.

Treisman, D. 2011. The Return: Russia's Journey from Gorbachev to Medvedev. New York: Simon and Schuster.

Treisman, D. 2015. "Income, Democracy, and Leader Turnover." American Journal of Political Science 59 (4): 927-942.

Way, L.A. 2015. Pluralism by Default: Weak Autocrats and the Rise of Competitive Politics. Baltimore: Johns Hopkins University Press.

World Bank. 2017. Russia Economic Report: From Recession to Recovery, no. 37. http://www.worldbank.org/en/country/russia/publication/rer (accessed October 15, 2017) 